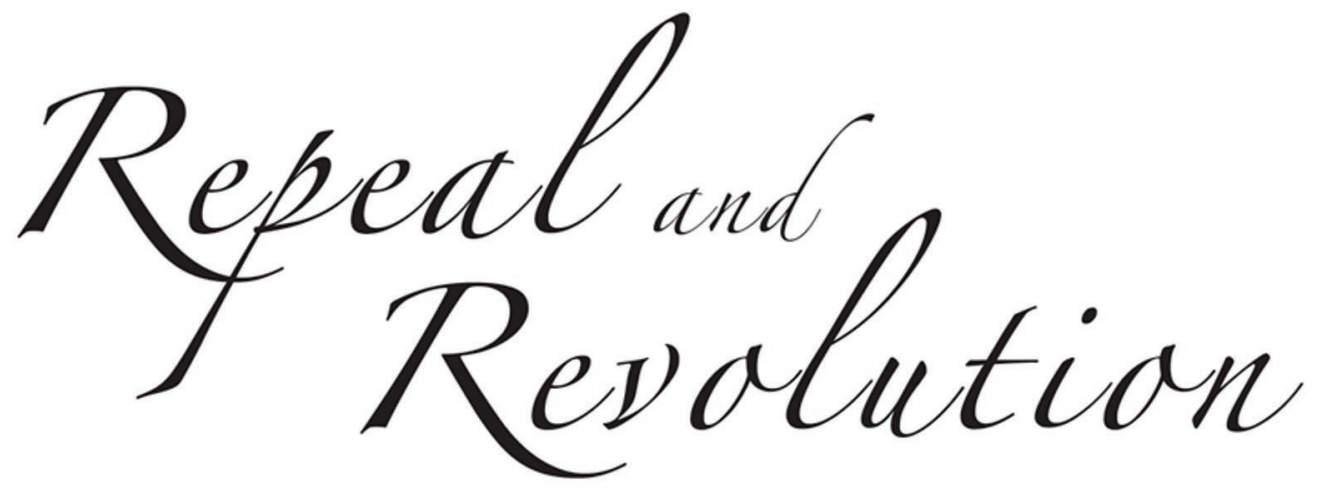

$1848 \quad$ I N I R E L A N D

C H R I S T I N E K I N E A L Y

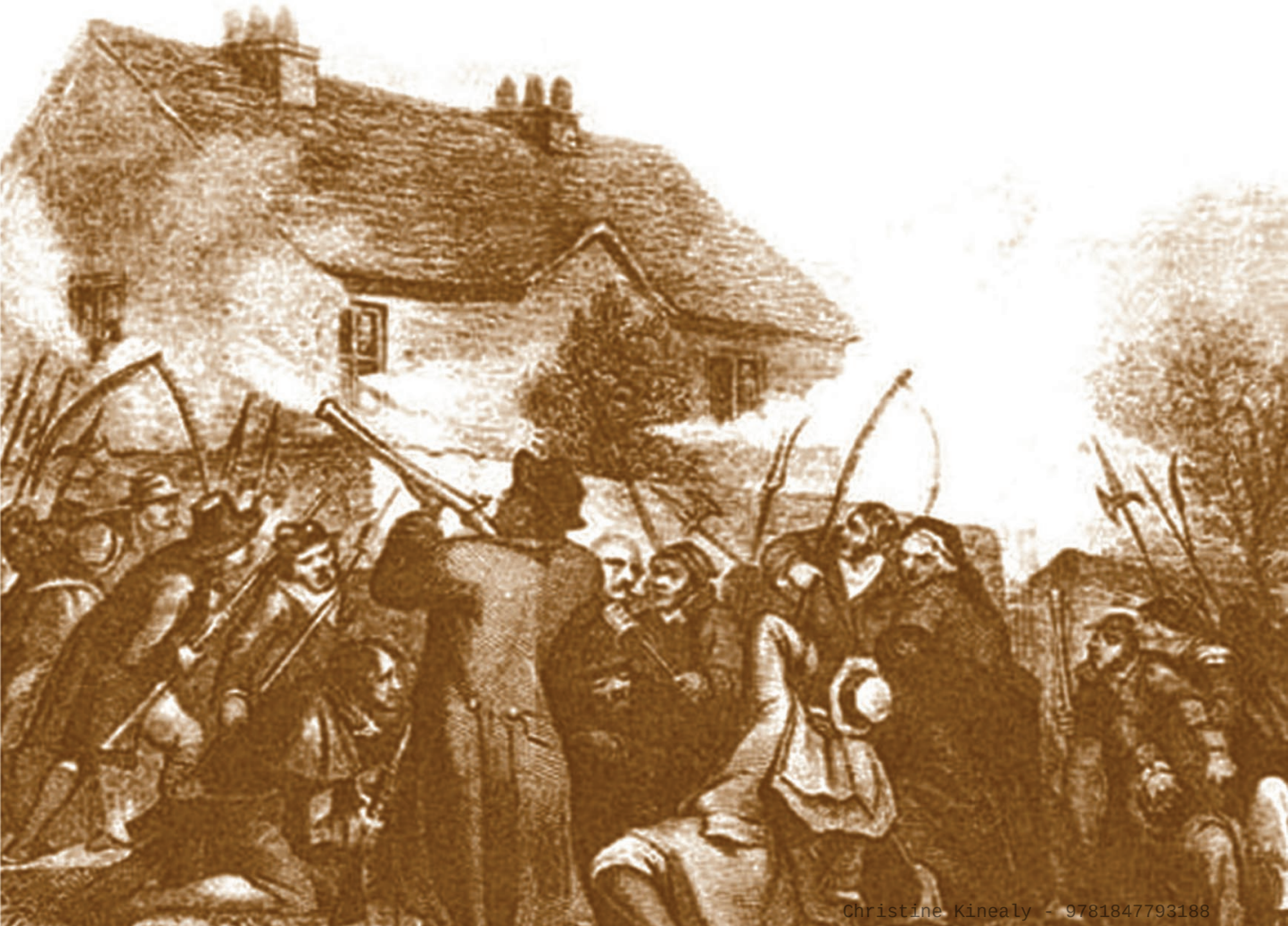




\section{Repeal and revolution}

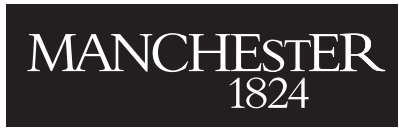

Manchester University Press 
Christine Kinealy - 9781847793188 Downloaded from manchesterhive.com at 04/26/2023 01:24:29PM via free access 


\section{Repeal and revolution 1848 in Ireland}

Christine Kinealy

Manchester University Press

Manchester and New York

distributed in the United States exclusively by Palgrave Macmillan 
Copyright (C) Christine Kinealy 2009

The right of Christine Kinealy to be identified as the author of this work has been asserted by her in accordance with the Copyright, Designs and Patents Act 1988.

Published by Manchester University Press

Oxford Road, Manchester M13 9NR, UK

and Room 400, 175 Fifth Avenue, New York, NY 10010, USA

www.manchesteruniversitypress.co.uk

Distributed in the United States exclusively by

Palgrave Macmillan, 175 Fifth Avenue, New York,

NY 10010, USA

Distributed in Canada exclusively by

UBC Press, University of British Columbia, 2029 West Mall,

Vancouver, BC, Canada V6T 1Z2

British Library Cataloguing-in-Publication Data

A catalogue record for this book is available from the British Library

Library of Congress Cataloging-in-Publication Data applied for

ISBN 9780719065163 hardback

ISBN 9780719065170 paperback

First published 2009

\section{$1817161514131211 \quad 100910987654321$}

The publisher has no responsibility for the persistence or accuracy of URLs for external or any third-party internet websites referred to in this book, and does not guarantee that any content on such websites is, or will remain, accurate or appropriate.

Typeset

by Action Publishing Technology Ltd, Gloucester

Printed in Great Britain

by CPI Antony Rowe Ltd, Chippenham, Wiltshire 